\title{
Illusion of Portrait Photography
}

\author{
He Yang \\ Huanghe Science and Technology College \\ Zhengzhou, China \\ E-mail:12509268@qq.com
}

\begin{abstract}
Nowadays, the relationship between photography and digital imaging technology has become closer than ever before, and most of the images we see every day have been processed by digital technology as well. Especially the evolution of APP which is based on mobile terminal equipment, and decoration and beautification of portrait photography have even omitted the user. As a result, countless "network beauties" stand out. Being cheated, people began to put the blame on the "illusion" created by post-photography technology for such a phenomenon. Yet when we look at the photography history once again, we will find that the illusion of portrait photography appear at the beginning of the invention of photography.
\end{abstract}

\section{Keywords—portrait photography; illusion}

\section{INTRODUCTION}

As the advanced animals, people will also naturally express a series of reactions towards themselves and the humanity itself such as self-regarding, self-protection, selfdisclosure, self-creation, self-revealing and self-criticism in addition to their reactions towards such outside world such as the city, the universe. Using painting to record images can be traced back to ancient times, and photography renders people a new way to record their life and themselves. As a result, the camera in one's hands will not only focus on himself, but also others of the same kind. Camera changes people's image into photograph to prove one's existence, to please others, to entertain himself, or to explain inner thoughts and feels through records of these people's images...

More often, people will stress objectivity of the photography, however, no matter for what purpose it is photographed, most of the numerous images presented to us will contain strong subjective consciousness which is not limited to the photographer, but also includes the people who is (are) facing the camera (including the photographer himself). This kind of strong subjective consciousness makes the images of many people don't seem to as objective as the photo itself. And the images become an illusion to be controlled and manipulated (even if such control and manipulation are just for making up technical defects or to make it good-looking), or simply to create an image or put the character into a man-made dreamland. At this point, illusion and dreamland will remind people of the characteristics of digital imaging technology of "false".
Though the pixel movement and displacement may change the real world and human appearance, the people and their illusions that appear in dreamland earliest are the beginning of photography history.

\section{ILLUSION OF ONESELF}

Today, the countless self-portraits from media platform with MicroBlog and $\mathrm{WeChat}$ as its representative make us realize that people have impulse to make camera focus on themselves, of course, the artists taking photography as creation means are no exception.

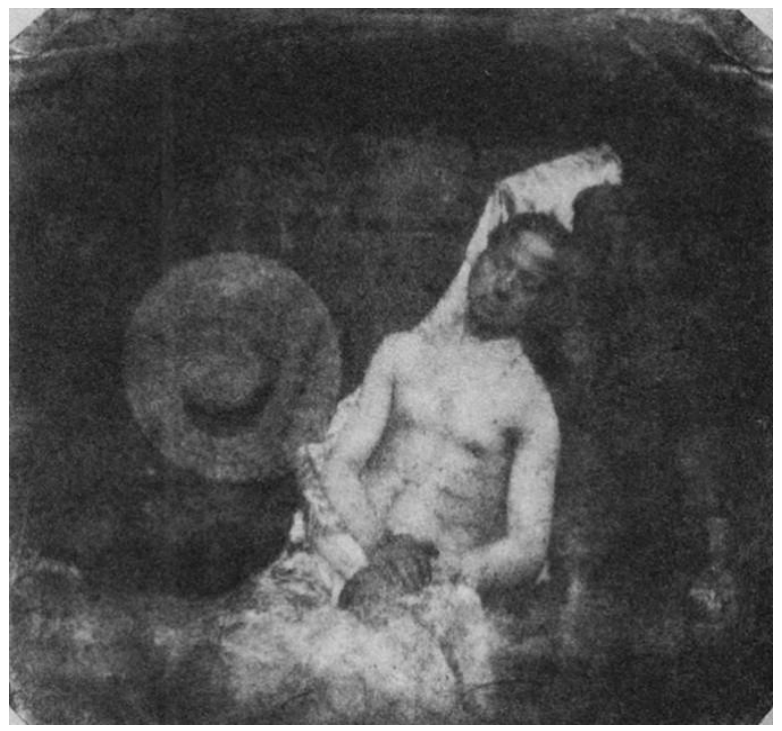

Fig. 1. Hippolyte Bayard. Self-Portrait as a Drowned Man, 1840.

Actually, photography history can also provide a solid evidence for this viewpoint. The first self-portrait in the world - Self-Portrait as a Drowned Man photographed by French Hippolyte Bayard "Fig. 1", has fully expressed people's self-regarding, self-protection, self-disclosure and self-creation towards themselves. In this photo, the one who has played "the drowned" is Hippolyte Bayard, the author of this photo. And he is another one who has contested with Daguerre for invention rights of photography besides William Henry Fox Talbot. In May 1839, he once showed his photography method on paper base for positive exposure to Arago, however, Arago has applied for a patent of photography for Daguerre prior to Bayard. Therefore, he just gave 600 French Francs to Bayard with an excuse of that 
Bayard shall continue to perfect his study results (French government prepared a proposal for accepting Daguerre's photography method by strong request of Arago, which reads "As for western cameras, the information provided by photography method of Daguerre and its future development, annual salary of 6000 French Francs shall be granted to Daguerre.... $)^{1}$. After Daguerre's photography method had been announced by French Academy of Sciences for six months, Bayard showed his study results to French Academy of Sciences, yet the invention right of photography has been put in Daguerre's back pocket. As result, angry Bayard dressed himself like a half-naked drowned man to make the Self-Portrait as a Drowned Man, and wrote his permanent condolences to this drowned photographer on the back of this photo "The government that has given great support to Daguerre announced that it cannot give any help to Bayard, so the unfortunate person drowned himself. Oh, life! He has spent several days in the morgue, but no one came to claim him. Ladies and gentlemen, please get ready for everything you may smell and see, for this gentleman's face and hands have begun to decay "2. What Arago have done makes Bayard's invention relevant to photography unable to enter into the public's view, which makes disappointed Bayard has to choose putting himself in an imaginary environment to take photo by himself, expressing his dissatisfaction and his inner thought to the public.

In Bayard's work, he showed a naked image in the photo, indicating the important position of discussion about relationship between "self" and "body" in western philosophy; Descartes and Freud have talked about this problem. The artist's longstanding preference for using his image or body to conduct artistic creation may be seen from the self-portrait of countless painters and photographers. Contemporary artists will absolutely not abandon this useful tool - photographing technology. Some contemporary artists have made the camera focus on themselves again, and present a fantasy and strange image to the audience through changing their bodies, so as to explore their existence value and to seek self-positioning "Fig. 2", "Fig. 3".

Danny Treacy, who comes from England, is a representative artist among them. He has conducted reorganization and collocation of recycled clothing and cloth materials and put them on. The shapes of those things called clothing have been changed and their original function has lost as well, becoming a strange thing casually wrapped the artist's skin. This set of old clothing with original master's breath has completely concealed the original features of the artist who is in the dark, making us unable to distinguish the origin, age gender of this creature looking like an illusion. We may ask is he/she human? The fuzzification of self identity has given people the awareness of some sort of replacement and absent, also made people themselves

\footnotetext{
${ }^{1}$ International Center of Photograpny of New York, America: International Centern of Photography Encyclopedia of Photography, Beijing: Chinese Photography Publishing House, P.138.

2 [British] Susan Bright, Fu Aidi. Auto Focus: The Self-Portrait in Contemporary Photography $[\mathrm{M}]$. Beijing: World Publishing Corporation, Post Wave Publishing and Consultation (Beijing) Co., Ltd., 2013, P. 8
}

disappear under the surrounding of cloths whose original existence is for human.

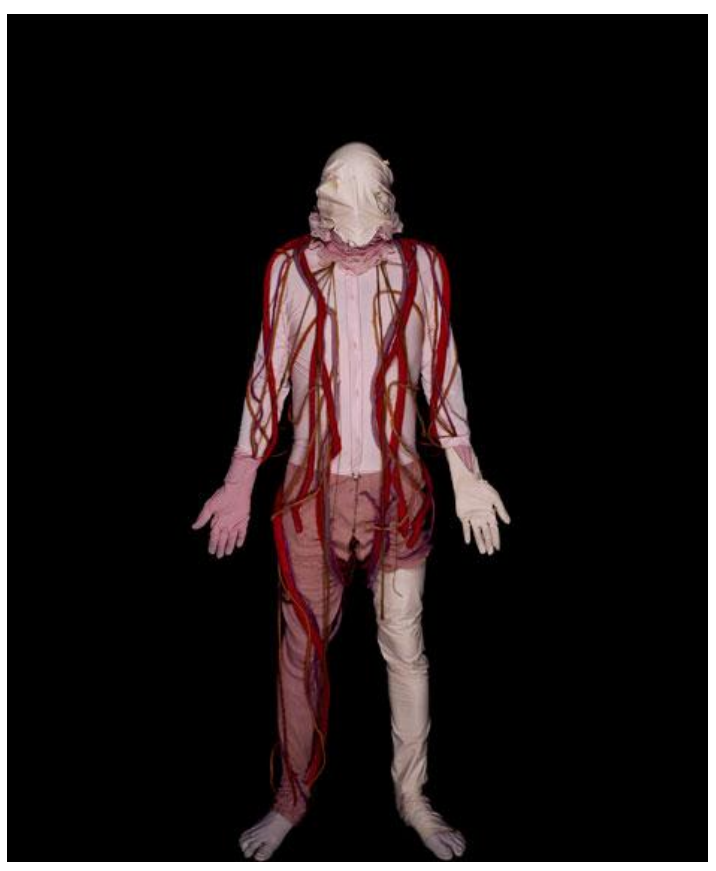

Fig. 2. Danny Treacy. "Them 19". 2007.

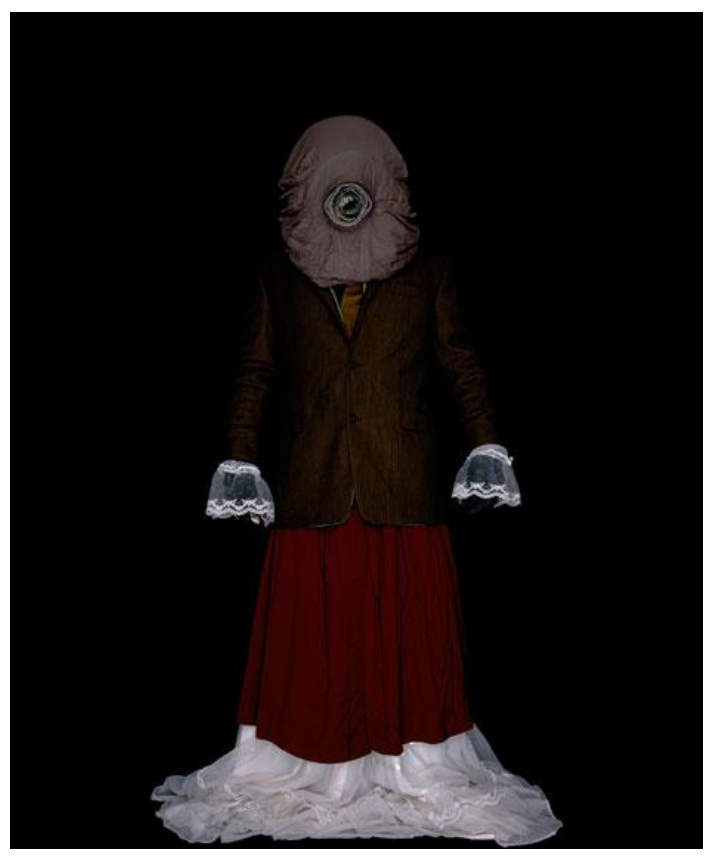

Fig. 3. Danny Treacy. "Them 8". 2005.

\section{PORTRAIT ENVELOPED BY IMPERFECTION}

Because portrait art may record objectively through people's appearance to reflect their spiritual world, it has aroused great attention after the Italian Renaissance movement. And as a new carrier and media, photography has been tightly bounded to portrait art since the beginning of its invention, which has extended the portrait painting. In 
portrait photography practice, however, the disadvantage of Daguerre's photography method of long exposure has soon been revealed. Long exposure is unfavorable to capture portraits, and any tiny movement of the character will result in fuzzy of the final image. Therefore, while photographing portrait in the early days, an additional tool, namely a support used for supporting a character's arm or head shall be prepared "Fig. 4". From this photo of Wheeler, it is not hard to find that the photographer and the subject is the same person, so we can conclude that this is photographic film composited through darkroom techniques. Although at the end of 19th century when this photo was born, this practice of portrait photographing with the head supported was no longer popular or was no longer needed due to the development of photosensitive material and the invention of camera lens with larger amount of light (petzval lens), we still can learn about the condition of portrait photographing in early days through this photo.

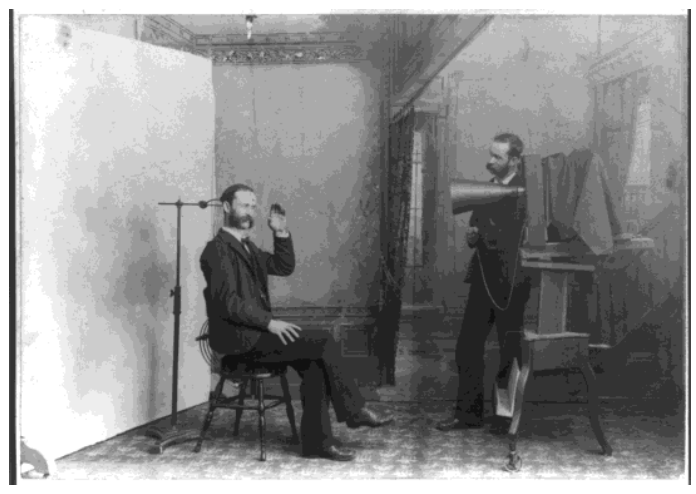

Fig. 4. A.H. Wheeler. "A Photographer Plan to Take a Portrait for Himself". 1893

In 1843, from the picture of Jabez Hogg Making A Portrait in Richard Beard 's Studio (Fig. 5) by an unknown photographer, and the stiff posture and hand movements (left hand clutching the armrest of the chair, and right hand holding in a fist) selected to ensure a clear image, it is not difficult to make a judgment that under the then photographing condition, if the subject want to get a clear picture, he/she shall keep a stable or stiff gesture for quite a long time (for modern photography) "Fig. 5".

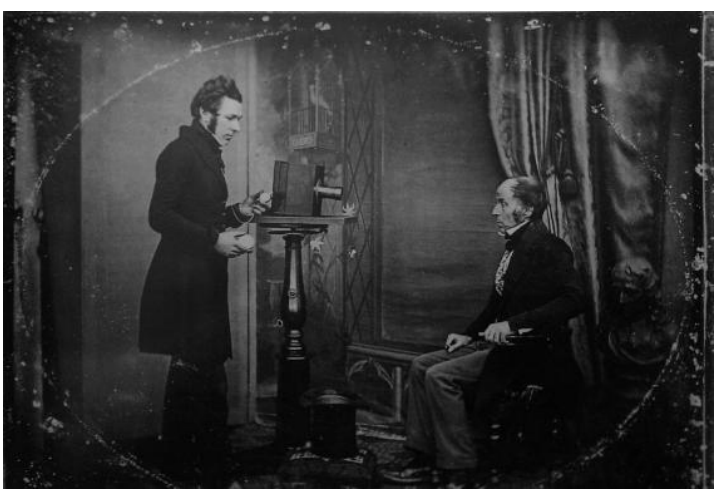

Fig. 5. Anonymous Photographer. " Jabez Hogg Making A Portrait in Richard Beard 's Studio". 1843.
This is an important reason for the stiff movement and serious facial expression of the subject when we are watching the portrait photographing works using Daguerre's photography method. "Fig. 6" In this kind of portrait, although photography may render the subject a more accurate portrait than painting in a shorter time (relative to portrait painting) through its unparalleled replication capacity, people's facial expression tends to be "antique serious" 3 "Fig. 6" due to the limitation of technical conditions and too much interruption to the subject by the photographer (the posture and others in order to reduce virtual image). Such expression cannot reflect the subject's inner spiritual world as accurate as expressing his appearance. Even if there are some reflection, that may be a spiritual world disguised by the subject and manipulated by others, and revealed by the subject willingly. Therefore, there are reasons for us to believe that those portraits are more likely the illusion brought by photography.

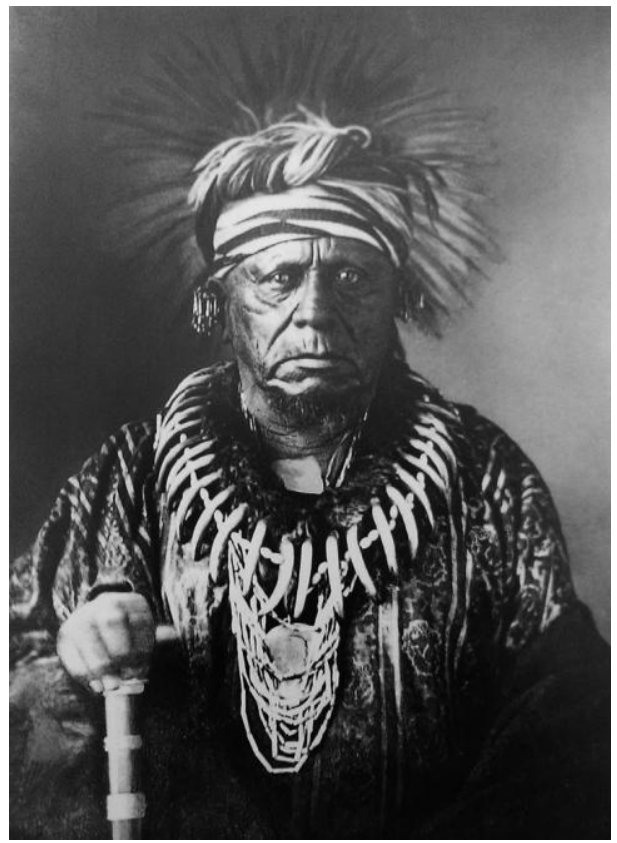

Fig. 6. Matos Easterl. The Indian Chief. 1847.[4]

Long exposure may be a kind of defects for the people who live in the early time of invention of photography, as they just reluctantly created people's illusion. Yet the contemporary photographers take advantage of long exposure, for instance, in Chapter I, we have talked about that time may erase something, and it may leave something as well, which include absolutely the trace of light for photography to "survive". Alex• DeForest, an American artist, has taken advantage of this characteristic to present a bizarre portrait through lightening himself by flashlight and the trace generated by optical fiber toys in a complete dark environment "Fig. 7".

\footnotetext{
3 Archaic period of ancient Greek ( 7 th century BC- 6 century BC), the stereotyped smile particular to the face of Greek statue. "antique serious" refers to the stereotyped serious and stiff facial expression in early portrait photography.
} 


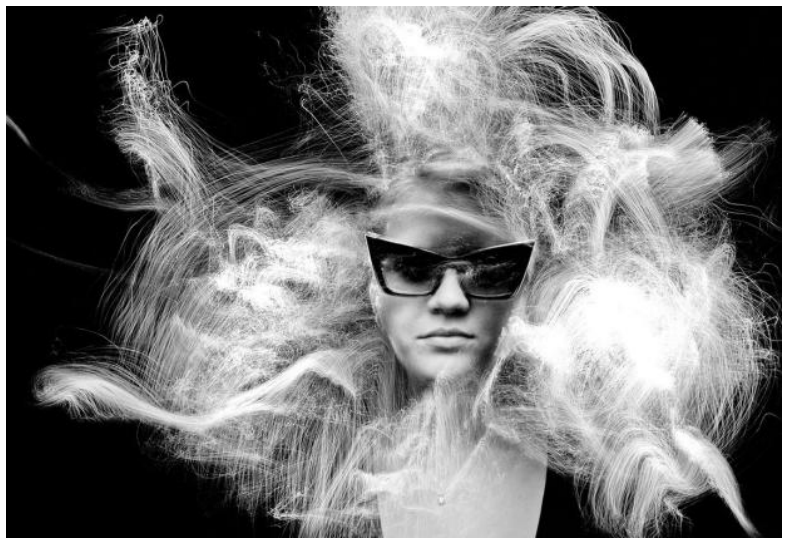

Fig. 7. Alex• DeForest. "Portrait".

\section{ROLE Play}

The stiff expression is clearly not the ultimate goal of truth for human. In the study following Daguerre's research, the camera lens with larger amount of light were invited and manufactured, and the Wet Plate Collodion Process with faster photoreception has also been invited. Compared with previous processing technology, Wet Plate Collodion Process can not only guarantee the clearness of image, but also make multi images output be realized through Albumen Print. With the promotion of technology development, portrait photography has adapted the mode of commercial development and operation. Compared with the portraits photographed by Daguerre's photography method, the subjects' movements and facial expressions in the portraits photographed by new process seem to be more natural and richer, and the previous "antique expression" faded gradually.

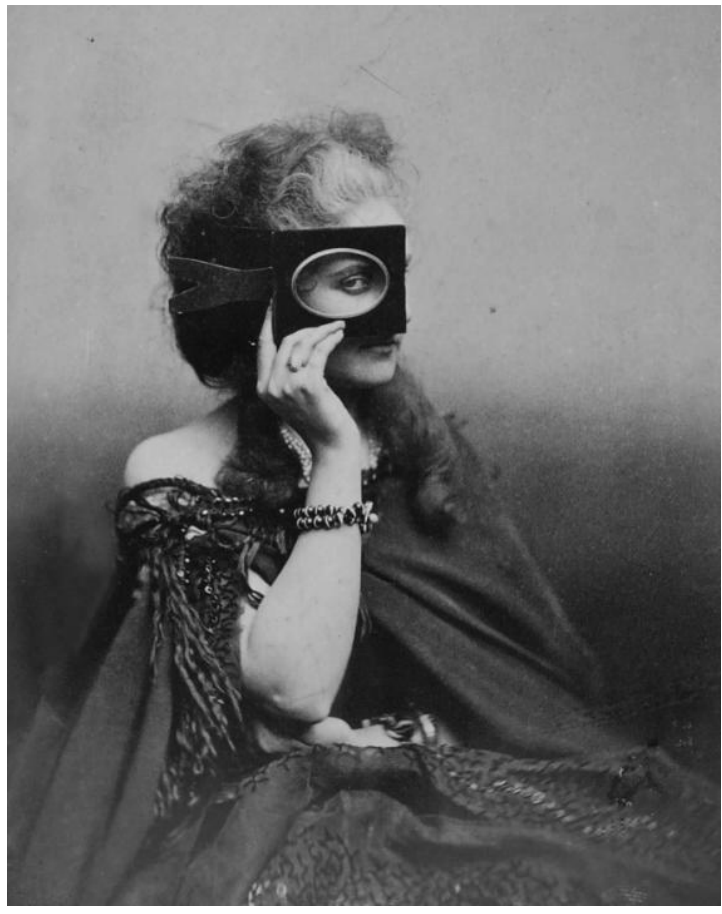

Fig. 8. Louis Pirson. Countess Castiglione. About 1860
In Louis Pirson's works, the bare shoulders, oval photo frame and the natural eye expression of Countess Castiglione, the mistress of Napoleon III, make the whole picture full of flirting "Fig. 8". However, this is just one of the 400 pictures in the period of 40 years' cooperation between Pirson and the Countess. The "true quality" of Countess hasn't been shown in those pictures, but the Countess has dressed as a girl "Fig. 8", historical figure, mythological figure or the figure in art history as shown in the picture. When we have learned about this, we may have a new evaluation on this picture: this picture may be just one of the illusions the Countess uses to please herself.

Such role-play portrait depending on portrait manipulating technology which can bring about pleasure, may not only bring in revenue for the photographers at that time, but in many of the scenic spots in the tourist cities nowadays, such role play may also bring in some commercial benefits for the photographers. And such examples may be common in current portrait photos and wedding pictures. For the masses, no matter for what purpose they shall take the pictures, the photographing process is boring mostly, although there may be some freshness in the beginning. What make them most excited are the costumes, props and their illusions created by the effects of light and shadow, or the visual adventure, excitement and comfort brought by their illusions created in the poor setting... Maybe most of them, or even those photographers who take pictures for them, may not be able to understand that, compared with the pictures of the Countess 150 years ago, these so-called artistic photos that bring about pleasure for the subjects, seems not that artistic or even somewhat awkward, although both of them adopt the portrait manipulating technology. Maybe for the masses, using the truthful pictures to prove their beauty and youth, and to provide "evidence" that makes himself or herself be convinced that he/she has realized a dream in an unattainable environment, is more important than the artistic value of the picture itself.

The manipulating technology for illusion creation is also a method frequently used by the artists in contemporary photography art creation. Contemporary artist Fan Shunzan has made good use of this portrait manipulating technology in his work of How Much Time Allow to Dream, creating an illusion of a people in his dream "Fig. 9". In his works, the color printed background cloth becomes a carrier of the dreamland for his dream. In this picture, the dressing on the man's upper body and his appropriate expression fit the illusion created by the background cloth. However, with our eyesight moves down, the contrast generated by the harsh reality make us couldn't help sighing. When we look at the background cloth which carries dreams again, the offending fold and the rough picture drive us away from the dream. Perhaps, it is the very fold and roughness in real life makes us spend time on games or soap opera which enable us to obtain dream illusion easily, and go far away from the real ideal and dream again and again. However, when we look back the people in those pictures, their satisfying expression and pretentious or even funny posture may touch us deeply. Actually, dream may not necessarily that great, we will be 
satisfied easily. The dream may be just the thin background cloth which is no richer than the reality. Those folds and roughness remind us that the more insistence and carefulness on the dream, less flaw will be, and the closer the dreams will be...

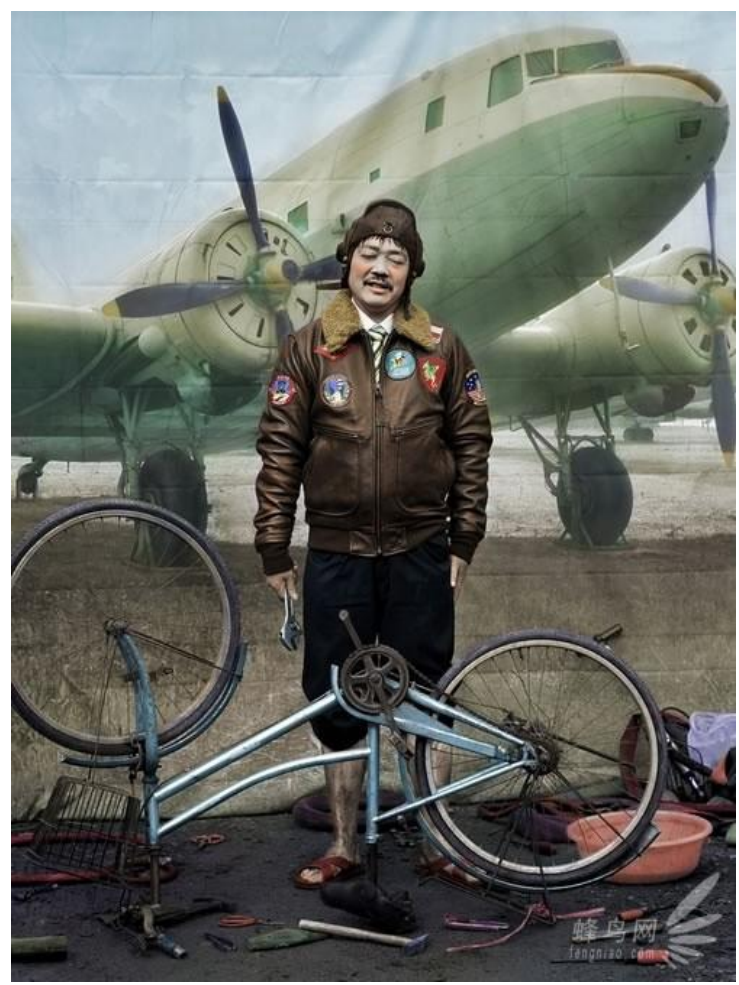

Fig. 9. Fan Shunzan. "How Much Time Allow to Dream".

The experience of Fan Shunzan himself may explain this very well. This piece of work has cost his everything and is his desperation work. He almost has given up his dream. In interview by Fengniao Net, he once said that "I just wanted to finish it before Pingyao Photography Festival, and try a last time to see others' response on my work, if it is good, I will insist to create no matter how hard it will be, but if the response is not that good, I will rethink whether or not I am suitable for developing such a career, and if not, I will put it aside, absolutely life shall be of first importance." Fortunately, the young man's persistence for his dream hasn't been ignored again, and his work gained recognition at last. Fan Shunzan has been awarded the outstanding photographer in art of Pingyao International Exhibition 2013 by virtue of this work. Not only the work of this young artist, but also his experience have told us that, if possible, please give more time to the dream, the reality is not that harsh as what we have seen sometimes...

\section{REFERENCES}

[1] Gerry Badger. The spirit of Photography: How Photography Has Changed Our Life [M]. Translated by Zhu Youruo. Hangzhou: Zhejiang Photographic Press, 2011

[2] usan Bright, Fu Aidi. Art Photography Now [M]. Translated by Lv Mengzhe. Beijing: World Publishing Corporation, Post Wave Publishing and Consultation (Beijing) Co., Ltd., 2013
[3] Susan Bright. Auto Focus: The Self-Portrait in Contemporary Photography $[\mathrm{M}]$. Translated by Wang Lang. Beijign: Post Wave Publishing and Consultation (Beijing) Co., Ltd., World Publishing Corporation, 2013

[4] Susan Sontag. On Photography [M]. Translated by Huang Canran. Shanghai: Shanghai Translation Publishing House, 2008

[5] American New York Institute of Photography, Photographic Materials of New York Institute of Photography [M], Beijing: Chinese Photography Publishing House, 2008

[6] Glenn M Rand, Richard D. Zakia. Teaching Photography [M]. Translated by Li Kunyan. Beijing: World Publishing Corporation, Post Wave Publishing Company, 2013

[7] Terry Barrett, Critizing Photographs [M]. Translated by He Jihui. Beijing: World Publishing Corporation, Post Wave Publishing Company, 2013

[8] Edited by Michael R.Peres. Encyclopedia of Photography [M]. Translated by Wang Rui. Beijing: World Publishing Corporation, Post Wave Publishing Company, 2013

[9] Liz Wells. Photography: A Critical Introduction [M]. Translated by Li Ji and Chen Weisi. Beijing: Posts \& Telecom Press, 2012

[10] Naomi Rosenblum. A World History of Photography [M]. Translated by $\mathrm{Bao} \mathrm{Su}$, Tian Caixia and $\mathrm{Wu}$ Xiaoling. Beijing: Chinese Photography Publishing House, 2012

[11] Roland Barthes. Bright Chamber [M]. Beijing: China Renmin University Press, 2013

[12] Eric Renner. Pinhole Photography [M]. Translated by Mao Weidong. Beijing: World Publishing Corporation, 2011

[13] John Ingledew. PHOTOGRARHY (International Photography Art Course ) [M]. Translated by Ren Yue. Beijing: China Youth Publishing Group, 2008

[14] Bruce Barnbaum. The Art of Photography [M]. Translated by Fan Zhiyi. Beijing: Posts \& Telecom Press, 2012

[15] Henri Cartier-Bresson. The Eyes of Thoughts: Cartier-Bresson's Theory on Photography [M]. Translated by Zhao Xin. Beijing: Chinese Photography Publishing House, 2013 